\title{
WOJSŁAW CZUPRYŃSKI \\ Społeczno-kulturowy i religijny wymiar globalizacji w życiu współczesnej rodziny
}

Globalizacja jest procesem wielowymiarowym, obejmującym przestrzeń życia politycznego, gospodarczego, społecznego, kulturalnego, a także religijnego. Jej konsekwencją nie jest zatem jedynie unifikacja sposobu produkcji czy dystrybucji dóbr materialnych, ale także upowszechnianie lub wytworzenie nowego stylu życia człowieka we wszystkich jego przejawach, także w wymiarze religijnym ${ }^{1}$. Globalizacja jest generowana prądami ekonomicznymi i gospodarczymi, czego najbardziej widomym znakiem są coraz liczniejsze i coraz bardziej znaczące ogólnoświatowe instytucje finansowe, korporacje przemysłowe i handlowe oraz koncerny medialne. Ogromny rozwój, który dotyczy różnych dziedzin ludzkiej aktywności (komunikacji, ekonomii, przemysłu), buduje nową, nieznaną dotychczas ludzkości sieć zależności ${ }^{2}$. Poszczególne procesy oddziałują na siebie na zasadzie sprzężenia zwrotnego i są dla siebie wzajemnie swoistym rodzajem akceleratora zmian. W tym wymiarze można mówić o globalizacji jako procesie samorzutnym i nieuchronnym.

Trzeba jednak mieć świadomość, że globalizacja i wielokulturowość jest także ściśle określonym projektem społecznym. Obok procesów samorzutnych można dostrzegać również takie, które mają charakter intencjonalnych działań zmierzających do urzeczywistniania wizji społeczeństwa wielokulturowego.

Wojsław C Z U P R Y Ń S K I: ks. dr., adiunkt w Katedrze Teologii Pastoralnej i Katechetyki na Wydziale Teologii Uniwersytetu Warmińsko-Mazurskiegow Olsztynie, e-mail: czuwoj@wp.pl

${ }^{1} \mathrm{~J} . \mathrm{B}$ a rd z i e j: Zakorzenienie i alternacja: tożsamość jednostki $w$ społeczeństwie tradycyjnym. W: Tożsamość i jej przemiany a kultura, Pod redakcją Piotra Olesia. Lublin 2008 s. 240.

${ }^{2}$ A. G i d d e n s: Europa w epoce globalnej. Warszawa 2009 s. 11. 
Coraz odważniej postuluje się demontaż obowiązujących i niekwestionowanych przez wieki wartości i systemów społecznych ${ }^{3}$. Szczególną egzemplifikacją takich działań może być polityka migracyjna prowadzona w ostatnim czasie przez rządy niektórych państw europejskich.

Próby realizacji koncepcji społeczeństwa wielokulturowego w istotny sposób wspierane są przez idee postmodernizmu. Ich wyznawcy, kwestionując znaczenie kultury i dziedzictwa minionych pokoleń, odrzucają naturalny fundament ładu społecznego ${ }^{4}$. Świat, jak twierdzą postmoderniści, jest na tyle złożony, wieloznaczny i wielopłaszczyznowy, że nie jest możliwe ujęcie jego fundamentalnych struktur w jakikolwiek system myśli. Nie ma zatem żadnej prawdy obiektywnej i niezmiennej. Wszystko staje się względne, naznaczone subiektywizmem. W każdym przypadku trzeba konstruować nowe kryteria, które będą odpowiadać poszczególnym przypadkom indywidualnym ${ }^{5}$. Od dziesięcioleci jesteśmy w Europie świadkami sporu pomiędzy zwolennikami zachowania kulturowej tożsamości naszego kontynentu a wyznawcami idei szerokiego otwarcia się na różnorodne kultury.

Niezależnie od rodzaju czynników generujących zjawisko globalizacji i wielokulturowości można przewidywać, że procesy wchodzenia $\mathrm{w}$ relacje międzykulturowe w Polsce będą ulegały dalszej intensyfikacji. I choć skala tego procesu będzie prawdopodobnie zdecydowanie mniejsza niż w krajach Europy Zachodniej, to jednak można mówić o istotnej zmianie w polskim społeczeństwie polegającej na przechodzeniu „od homogeniczności do heterogeniczności, od jedności do różnorodności”' Trzeba mieć świadomość, że wielokulturowość nie jest jedynie prostym występowaniem różnych kultur w określonej społeczności. To przede wszystkim zbiór zasad określających charakter współżycia społecznego w warunkach realizacji pluralizmu kulturowego, tak by wyrównywać prawa i szanse uczestnictwa oraz niwelować napięcia i konflikty. W wymiarze indywidualnym wielokulturowość łączy się z obecnością całego zespołu cech psychokulturowych, takich jak: dominujące wzory kulturowe, tożsamość kulturowa, zorientowanie na określoną hierarchię wartości i wynikających z tego implikacji o charakterze społecznym, politycznym, ekonomicznym, religijnym ${ }^{7}$. W czasach ponowoczesnych, "«rodzina» przestaje być instytucją naturalną, w którą się po prostu «wchodzi», tak jak - zgodnie z prawami biologii - wchodzi się w wiek dojrzały"8.

${ }^{3}$ A. Z w o li ń s k i: Wprowadzenie do rozważań o narodzie. Kraków 2005 s. 235.

${ }^{4}$ A. B r o n k: Zrozumieć świat wspótczesny. Lublin 1998 s. 54-55.

${ }^{5}$ R. G e i s l e r: Jednostka i społeczeństwo w postmodernizmie. Częstochowa 1999 s. 49.

${ }^{6}$ D. B e 11: Kulturowe sprzeczności kapitalizmu. Warszawa 1994 s. 29.

${ }^{7}$ T. P a l e c z n y: Interpersonalne stosunki międzykulturowe. Kraków 2007 s. 176-177.

${ }^{8}$ H. Ś w ida-Z i e m ba: Młodzież końca tysiąclecia. Obraz świata $i$ bycia $w$ świecie. Warszawa 2000 s. 469. 
Rodzą się pytania o konsekwencje tych kulturowych przemian dla funkcjonowania małżeństwa i rodziny. Na ile obecność małżonków wywodzących się z odrębnych kręgów kulturowych stanowi ubogacenie ich związku, a na ile zagrożenie dla jedności i trwałości budowanej na tym związku rodziny? Jaki ma to wpływ na wychowanie i rozwój ich dzieci? Jakie są konsekwencje dla sposobu celebrowania wiary $\mathrm{w}$ rodzinie?

\section{Zderzenie kultur}

Związana z globalizacją migracja prowadzi do zderzenia kultur i tzw. ,szoku kulturowego", czyli doświadczenia wstrząsu i zaskoczenia spowodowanego zetknięciem się z czymś nowym, nieznanym. Towarzyszy temu poczucie osamotnienia, niezrozumienia, utraty bezpieczeństwa. Szok kulturowy może prowadzić nawet do izolacji, tworzenia swoistego getta w otoczeniu obcej kultury. Nawet wysoka tolerancja wobec odmienności i dobra wola nie są w stanie uchronić przed doświadczeniem frustracji i lęku. Można wskazać na dwa typy postaw będących efektem zaistnienia szoku kulturowego: (a) zwrócenie się do swoich rodzimych treści i form (wzorów) kulturowych i coraz ostrzejsze przeciwstawianie się obcym treściom i formom lub (b) porzucenie (zanegowanie) swoich rodzimych kulturowych wzorów w celu jak najszybszego przyswojenia sobie wzorów obcych ${ }^{9}$.

Stopień odmienności kulturowej determinuje liczbę problemów występujących między małżonkami. Czynniki - elementy kultury, które generują problemy między małżonkami, można klasyfikować. Geert Hofstede wymienia następujące: dystans władzy, kolektywizm i indywidualizm, kobiecość i męskość oraz unikanie niepewności ${ }^{10}$.

Pierwszy z wymienionych aspektów kultury - dystans władzy, wskazuje na rodzaj relacji pomiędzy członkami danej społeczności w sytuacji społecznej zależności. Duży dystans, obecny na przykład w krajach islamskich, uwidacznia się brakiem swobodnego dialogu, dużymi trudnościami w komunikacji uczuć. Mały dystans - stwarza możliwość bardziej bezpośrednich relacji, wymiany poglądów, niezależnie od zajmowanego stanowiska w hierarchii społecznej. Ten sposób relacji w większym stopniu znamionuje społeczeństwa Europy Zachodniej.

Kolektywizm i indywidualizm to kolejne kryterium, które ukazuje wiodącą hierarchię wartości w danym społeczeństwie, a przede wszystkim zależność pomiędzy dobrem jednostki i dobrem społeczeństwa. Kolektywizm charakteryzuje

${ }^{9}$ Szok kulturowy W: Encyklopedia. Kultura - sztuka, t. IV. Red. A. Grzegorczyk. Poznań 1997 s. 302.

${ }^{10}$ G. H o f s t e d e: Kultury i organizacje: zaprogramowanie umystu. Warszawa 2000 s. 86-87. 
bardziej społeczeństwa ubogie lub/i te, w których władza ma charakter autorytarny lub totalitarny.

Męskość i kobiecość - ten wymiar opisuje, na ile odgrywane role społeczne, w ramach społecznej umowy, tradycji, są związane z płcią. Na przykład takie cechy, jak: czułość, wrażliwość, ciepło emocjonalne, skromność, będą bardziej charakteryzowały społeczny i zawodowy profil kobiety. Z kolei od mężczyzn będzie się oczekiwało takich cech, jak: asertywność, twardość, nakierowanie na sukces zawodowy i materialny ${ }^{11}$.

Unikanie niepewności - to inaczej stopień bezpieczeństwa i przewidywalności. Im wyższy stopień społecznej organizacji, tym mniejsze poczucie zagrożenia. Poziom bezpieczeństwa zapewnia między innymi sprawne państwo funkcjonujące na podstawie mądrego i dobrze egzekwowanego prawa ${ }^{12}$.

W świetle nawet tak pobieżnej charakterystyki możliwych różnic kulturowych zarysowuje się szeroki obszar wyzwań i zagrożeń dla jedności małżeństwa. Heterogamia dotycząca przede wszystkim takich cech, jak: narodowość, wyznanie, rasa, stanowi poważne niebezpieczeństwo dla trwałości małżeństwa. W zależności od miejsca zamieszkania i stopnia tolerancji danej grupy społecznej - zwłaszcza, gdy jest to środowisko jednorodne kulturowo - może też spotykać się z kolejnym wyzwaniem, jakim są brak społecznej akceptacji i wykluczenie. Poprzez proces stereotypizacji i uogólnienia przypisuje się określone cechy osobowościowe wszystkim ludziom pochodzącym z tego samego kręgu kulturowego. Ocena oparta na tego typu stereotypie, wzmocniona bezmyślnym powielaniem w przestrzeni publicznej, jest nieuczciwa i często bardzo krzywdząca. Prowadzi do zniekształcenia percepcji i błędnej interpretacji rzeczywistości ${ }^{13}$.

\section{Bariera języka}

Język jest podstawowym narzędziem budowania i przekazywania kultury. Jest on nie tylko systemem znaków służących przekazywaniu konkretnej informacji w określonym „tu i teraz”, ale także odbiciem sposobu myślenia i postrzegania świata. Dlatego jest uznawany za najważniejsze źródło informacji o kulturze. Jest nośnikiem takich treści, jak: zwyczaje, wiara, aksjologia, modele zachowań. Każda bowiem kultura dysponuje własnym kodem komunikacyjnym i systemem symboli ${ }^{14}$. Nie sposób do końca jej zrozumieć, nie poznając

11 Tamże s. 140.

12 Tamże s. 181.

${ }^{13}$ J. N i k i t o r o w i c z: Pogranicze tożsamości. Edukacja międzykulturowa. Białystok 1995 s. 40.

${ }^{14}$ T. P a 1 e c z n y: Interpersonalne stosunki międzykulturowe. Kraków 2007 s. 65. 
wcześniej języka. Kultura i język są bowiem względem siebie w permanentnej interakcji. Te dwa czynniki oddziałują na siebie na zasadzie sprzężenia zwrotnego. Często trudno ustalić, które zmiany i którego elementu są przyczyną, a które skutkiem.

Wysyłanie i odbieranie sygnałów w języku obcym jest połączone z ryzykiem nieporozumienia, powodując agresję lub wycofanie, frustrację i zniechęcenie do dalszej konwersacji. Może to dotyczyć nawet takich osób, które posiadły znajomość języka w stopniu zaawansowanym ${ }^{15}$. Sytuacja wydaje się jeszcze bardziej skomplikowana, gdy oboje małżonkowie posługują się językiem, który dla żadnego z nich nie jest mową ojczystą.

W tym kontekście nie można pominąć także znaczenia komunikacji pozawerbalnej, która nierzadko stanowi ważniejszy od języka mówionego kanał komunikacji. Gesty, mimika, ton głosu, kontakt wzrokowy i wszystkie inne sygnały niewerbalne różnią się w zależności od kultury. To, co dla jednej strony jest naturalne i instynktowne, nie jest oczywiste dla drugiej.

Jak w przypadku każdego kontraktu małżeńskiego, musi dojść do swego rodzaju kompromisu. W przypadku relacji międzykulturowej skala przedsięwzięcia jest zdecydowanie większa. Jego pomyślność zależy od szeregu czynników: stopnia podobieństwa partnerów, poziomu bariery językowej, umiejętności integracji odmienności obyczajów, postaw, wartości i zachowań. Zachowanie własnej tożsamości przy jednoczesnym poszanowaniu dla przekonań małżonka wymaga zarówno pewnego zasobu wiedzy, jak i umiejętności prowadzenia dialogu. Nieodzowne stają się takie cechy osobowościowe, jak: empatia, pokora, zdolność do przezwyciężania stereotypów, intelektualne zaangażowanie ${ }^{16}$.

Najlepszym spoiwem dla związku jest przyjęcie tego samego systemu wartości. Osoby, które wyznają podobne wartości, mają większą szansę na to, że ich związek będzie trwały, niezależnie od pochodzenia kulturowego.

\section{Migracje zarobkowe}

Częstym zjawiskiem dotykającym rodziny wielokulturowe jest czasowa rozłąka spowodowana migracją zarobkową. Wynika to z możliwości znalezienia pracy także poza krajem, w którym obecnie się mieszka. $Z$ obserwacji przeprowadzonych wśród Polek i Polaków pozostających w związkach małżeńskich

${ }^{15}$ D. M a t s u m o t o, J. J u a n g: Psychologia międzykulturowa. Gdańsk 2007 s. 356-357.

${ }_{16}$ M. S o be cki: Komunikacja międzykulturowa w wymiarze religijnym jako wyzwanie edukacyjne. W: Od wielokulturowości miejsca do międzykulturowości relacji społecznych. Wspótczesne strategie kreowania przestrzeni życia jednostki. Red. J. N i k i t o r o w i c z, J. M u s z y ń s k a, B. B o ć w in k i-K i l u k. Warszawa 2014 s. 107-118. 
z obcokrajowcami wynika, że rodziny wielonarodowościowe znacznie częściej są rodzinami niepełnymi lub - określając precyzyjniej - czasowo niepełnymi ${ }^{17}$.

Konsekwencje rozłąki z małżonkiem podejmującym pracę w innym kraju są obustronne. Dla małżonka przebywającego z dala od rodziny jest to wyobcowanie, stopniowe wyłączanie się z udziału w bieżącym życiu rodziny, z kolei dla małżonka pozostającego $\mathrm{z}$ dziećmi jest to przeciążenie obowiązkami domowymi i nasilającymi się trudnościami wychowawczymi, wynikającymi z braku drugiego z rodziców. Brak jednego z małżonków z powodu emigracji zarobkowej nie buduje wzajemnych relacji i nie prowadzi do odbudowy więzi małżeńskich. Samotność, brak wsparcia, miłości, bezpieczeństwa wzmacnia chęć nawiązywania relacji pozamałżeńskich, co w konsekwencji może doprowadzić do rozpadu małżeństwa ${ }^{18}$.

Częsta w rodzinach wielokulturowych emigracja zarobkowa jednego z rodziców powoduje zaburzenie podstawowych funkcji rodziny, takich jak zapewnienie ciągłości procesu socjalizacji, wsparcia emocjonalnego dziecka i transmisji kulturowej ${ }^{19}$. Dostrzega się dotkliwy brak symetrii w relacjach pomiędzy stale obecnym i dojeżdżającym rodzicem. Dzieci, choć tęsknią za nieobecnym rodzicem, przyzwyczajają się do rozwiązywania swoich problemów, korzystając ze wsparcia jedynie tego rodzica, z którym mieszkają ${ }^{20}$. Każda dłuższa nieobecność rodzica wpływa destrukcyjnie na dzieci, które odczuwają brak bezpieczeństwa $^{21}$. Pozbawione opieki i kontroli często stwarzają problemy wychowawcze na wszystkich szczeblach edukacji szkolnej, uciekają z lekcji, sięgają po narkotyki i alkohol, wpadają w nieodpowiednie środowisko, często przestępcze ${ }^{22}$. Dziadkom, którzy przyjmują rolę rodziców zastępczych, często trudno jest egzekwować dyscyplinę i stawiać odpowiednie wymagania.

Emigracja wywołuje uczucie obcości, a spotkanie z dawno niewidzianym rodzicem łączy się z frustracją. Występują także inne gwałtowne stany emocjo-

${ }^{17}$ I. Grabows k a-L u s ińs k a, M. Ok ó1s k i: Migracja z Polski po 1 maja 2004 r.: jej intensywność i kierunki geograficzne oraz alokacja migrantów na rynkach pracy Unii Europejskiej. Warszawa 2008 s. 30-32.

${ }^{18}$ Z. K a w c z y ń s k a-B u tr y m: Migracje. Wybrane zagadnienia. Lublin 2009 s. 74.

${ }^{19}$ W. Danilew i c z: Oblicza dzieciństwa w rodzinach rozłaczonych z powodu migracji zagranicznych rodziców. W: Problemy teorii i praktyki opiekuńczej. Pod redakcją Bożeny Matyjas. Kielce 2005 s. 73-84; T. Ole arczyk: Sieroctwo i osamotnienie. Pedagogiczne problemy kryzysu współczesnej rodziny. Kraków 2007 s. 291.

${ }^{20}$ E. S o w a-B e h t a n e: Rodziny wielokulturowe. Kraków 2016 s. 53.

${ }^{21}$ M. R o s t r o p o w i c z-M i ś k o: Wplyw migracji zarobkowych na sytuację rodzin Ślaska Opolskiego w świetle własnych badań ankietowych. W: Migracje - wyniki aktualnych badań $i$ analiz. Red. O. D ę b o w s k a. Kraków 2007 s. 109.

${ }^{22}$ W. Wa 1 k o w s ka: Spoleczne skutki eurosieroctwa. W: Migracje - wyniki aktualnych badań i analiz. dz. cyt. s. 117-120. 
nalne. Są nimi radość związana z przyjazdem rodziców oraz rozpacz wynikająca z ich wyjazdu. Ciągłe niepokoje, lęki, obawy i wątpliwości mieszają się ze sobą, powodując zaburzenia emocjonalne. Brak stabilizacji psychicznej, poczucia bezpieczeństwa, bliskości wywołuje zmiany w zachowaniu dziecka. Konsekwencją braku rodziców jest niska samoocena dziecka, które nie potrafi nawiązać poprawnych relacji ze swymi rówieśnikami oraz im zaufaće ${ }^{23}$.

\section{Spotkanie odmiennych religii}

Religijne konteksty globalizacji są rzadkim przedmiotem badań socjologów, psychologów i teologów. W niespotykanej dotąd skali dokonuje się transmisja systemów religijnych i ich asymilacja w całkowicie nowych środowiskach. To z kolei pociąga za sobą zjawisko nowego eklektyzmu religijnego - przenikania i akceptacji zapożyczonych elementów (okcydentalizacji religii Wschodu, orientalizacji chrześcijaństwa, a w obszarze chrześcijaństwa: protestantyzacji katolicyzmu i katolizacji protestantyzmu). Także w Polsce daje się zauważyć duże tempo wzrostu liczby katolików o religijności eklektycznej i selektywnej, przez co słabnie ich więź ze wspólnotą Kościoła. Można zatem mówić o dwóch nieodwracalnych procesach kulturowo-społecznych. $Z$ jednej strony dokonuje się prywatyzacja religii, z drugiej - marginalizacja Kościoła. Pierwszy proces stymuluje kształtowanie się religijności, która wyraża się głównie $\mathrm{w}$ emocjonalnym przywiązaniu do wiary oraz poszukiwaniu jedynie osobistego kontaktu z Bogiem. Drugi proces to przede wszystkim zerwanie związku katolików z Kościołem jako instytucją oraz porzucenie religijnych praktyk i doktryny. Owo „odkościelnienie” - odejście od zinstytucjonalizowanych form religijności i prywatyzacja duchowości może także przyczyniać się do tworzenia zupełnie nowych ruchów religijnych ${ }^{24}$. Ich twórcy często zgłaszają aspiracje do nadania swojej wierze wysokiej rangi.

Różnorodność religijna w rodzinie wielokulturowej może stymulować rozwój duchowy, mobilizując do poszerzenia wiedzy na temat własnej religii i głębszego jej uzasadnienia w konfrontacji z wiarą współmałżonka, ale także do poznania innych religii. Jeżeli odmienności religijnej towarzyszy wzajemny szacunek, który urzeczywistnia się poprzez wspólną celebrację świąt, to oprócz intelektualnego poznawania innej kultury i wiary otwiera się możliwość udziału w doświadczeniu religijnym małżonka. Wielokulturowość związku kryje w so-

${ }^{23}$ M. Wy żl i c: Migracja zarobkowa - zagrożeniem dla więzi matżeńskiej. „Cywilizacja” $2010 \mathrm{nr} 32$ s. $134-135$.

${ }^{24}$ M. Libis zowska-Żółtk owska: Nowe ruchy religijne $w$ globalnej przestrzeni. W: Religia i religijność $w$ warunkach globalizacji. Red. M. L i b is z ow s k a-Ż ółt k ow s ka. Kraków 2007 s. 200. 
bie pozytywny potencjał. Perspektywa integracji różnych tradycji i zwyczajów może czynić życie bogatszym i ciekawszym, poszerzać horyzonty małżonków i otwierać na nowe perspektywy ${ }^{25}$. Wartością dodaną takiego związku jest często wyższy poziom akceptacji i tolerancji.

Trzeba jednak stwierdzić, że tak harmonijne współistnienie dwóch odmiennych religii $\mathrm{w}$ przestrzeni małżeństwa i rodziny nie jest proste. Różnice religijne mają też negatywne konsekwencje, które w pełni ujawniają się dopiero w codzienności życia małżeńskiego, w obliczu konkretnych sytuacji i wyborów życiowych, szczególnie zaś wtedy, gdy wiąże się to z przyjęciem określonej aksjologii. Skala rozbieżności ujawnia się stopniowo w konfrontacji z pojawiającymi się sytuacjami życiowymi. Katalog spraw, stanowiący źródło konfliktów i sporów, jest bardzo szeroki. Może dotyczyć: ogólnej koncepcji życia, modelu wychowania dzieci, regulacji urodzin, sposobu odniesienia do rodziców, spędzania uroczystości religijnych, badań medycznych, wierności, bigamii, rozwodu, a także bardziej prozaicznych, jak: styl żywienia, ubioru, spędzania wolnego czasu $^{26}$. Ważnym, często nieuświadomionym obszarem rozbieżności jest model pożycia małżeńskiego. Wiele par pod wpływem onieśmielenia nie podejmuje tych tematów w okresie narzeczeńskim. W badaniach ankietowych przeprowadzanych systematycznie przez Ośrodek Formacji Małżeńskiej w Olsztynie uwidacznia się swoista ignorancja co do ustalenia wspólnych zasad w tej ważnej sferze życia małżeńskiego. Zaledwie ok. 40\% ankietowanych w mniejszym lub większym stopniu przyznaje się do podjęcia rozmowy z przyszłym małżonkiem na temat sfery życia religijnego ${ }^{27}$. Wszystkie wymienione wyżej problemy okazują się tym większe, im bardziej były ignorowane w okresie narzeczeńskim. Oczekiwania - często zresztą niewyartykułowane - dotyczące na przykład ewentualnej konwersji współmałżonka lub akceptacji dla określonej wizji wychowania dzieci okazują się nie do zrealizowania.

Ważną egzemplifikacją opisywanych wyzwań, jakie stają przed małżeństwami wielokulturowymi, są coraz powszechniejsze w naszym kraju małżeństwa polsko-arabskie. Małgorzata Stopikowska w przywołanym artykule przedstawia katalog podstawowych trudności. Wymienia następujące kwestie:

25 M. Walczak: Psychologiczna prognoza trwatości matżeństw dwukulturowych. „Problemy Rodziny” 2001 nr 1 s. 23.

${ }^{26}$ M. S to p i kow s ka: Malżeństwa polsko-arabskie: specyfika i zagrożenia. W: Nauki o rodzinie w stużbie rodziny. Red. J. S t a 1 a. Kraków 2014 s. 544.

${ }^{27}$ Ośrodek Formacji Małżeńskiej w Olsztynie działa w ramach Stowarzyszenia „Persona Humana”, opierając się na Statucie zatwierdzonym przez ks. arcybiskupa metropolitę warmińskiego. Zasadniczym celem jego działalności jest wspieranie małżeństw i rodzin w pokonywaniu kryzysów oraz organizowanie konferencji dla narzeczonych. Zob. http://personahumana.pl [dostęp: 21.06.2017]. 
- stosunek do wielożeństwa i rozwodu;

- komplikacje prawno-majątkowe związane z wpływem religijnego prawa szariatu na prawodawstwo w krajach arabskich;

- specyficzne obrzędy i obowiązki natury religijnej współmałżonka;

- odmienne wymagania religijne dotyczące wychowania w religii ojca lub matki ${ }^{28}$.

Autorka zwraca uwagę, że takie czynniki, jak: brak świadomości o podstawowych zasadach religii i kultury muzułmańskiej, niewłaściwa komunikacja, brak asertywności połączony z podatnością na podporządkowanie się drugiej stronie w związkach z wyznawcami islamu, wzmacnia niebezpieczeństwo wystąpienia przemocy ${ }^{29}$. Za prawdziwą zatem należy uznać ogólną konstatację, że „małżeństwa o dwóch bliskich sobie kulturach mają większe szanse na powodzenie, niż te różniące się nie dość, że narodowo, to także rasowo i religijnie" ${ }^{30}$. W sytuacji, gdy obie strony są osobami religijnie głęboko zaangażowanymi, dla których wiara stanowi główny punkt odniesienia, jeszcze większego znaczenia nabiera umiejętność komunikacji w przestrzeni religii.

\section{Wychowanie w rodzinie wielokulturowej}

Dom rodzinny ma specyficzne, niedające się z niczym porównać, możliwości wychowawcze. Istotnymi walorami tego środowiska są: naturalne więzi miłości, autorytet, spontaniczność, wspólnie spędzany czas, możliwość bezpośredniego wpływu poprzez świadectwo ${ }^{31}$. To wszystko stanowi niejako bazę psychologiczną, umożliwiającą nawiązanie prawdziwych osobowych relacji. Dziecko formuje atmosfera, którą ono na co dzień oddycha, potrzebuje też wokół siebie nie tyle nauczycieli, ile świadków. Rodzice odgrywają podwójną rolę w życiu dzieci. Są dla nich najważniejszym przykładem zachowań, a także pośredniczą w nawiązywaniu przez nie kontaktów z innymi podmiotami socjalizacji.

Niekwestionowaną wartością rodzin wielokulturowych jest większy potencjał przygotowania do funkcjonowania w wielokulturowym świecie. Dzieci $\mathrm{z}$ takich rodzin łatwiej oswajają się w odmiennej kulturze, szybciej nabywają kompetencje językowe. W rodzinach mieszanych narodowo dzieci mają dostęp

${ }^{28}$ M. S t o p i k o w s k a: Małżeństwa polsko-arabskie... s. 556.

${ }^{29}$ M. S t o p i k o w s k a: „Przeżyłam piekło” - oświadczenia kobiet w świetle pamiętników muzutmanek $i$ żon muzutmanów - między stereotypem a rzeczywistościq. W: Etykieta czy drogowskaz. Rola stereotypów w przestrzeniach edukacyjnej różnorodności. Red. M. Ło j k o, M. G r o c h a 1 s k a. Olsztyn 2013 s. 218-219.

${ }^{30}$ J. R o s to w s k i: Zarys psychologii malżeństwa. Warszawa 1987 s. 19.

${ }^{31}$ S. D z i e k oń s k i: Specyfika chrześcijańskiego wychowania w rodzinie. W: Wychowanie chrześcijańskie. Między tradycją a wspótczesnością. Red. A. R y n i o. Lublin 2007 s. 700-701. 
do dziedzictwa obu ojczyzn swoich rodziców. To zdecydowanie poszerza potencjał rozwojowy, otwierając szerokie perspektywy funkcjonowania w dorosłym życiu. Znajomość kilku języków, różnych modeli społecznych relacji zwiększa możliwość zdobycia pracy. Są to bardzo wymierne i praktyczne korzyści w kontekście coraz większej globalizacji i rozbudowanej sieci społecznej. Wśród walorów wychowawczych rodziny dwukulturowej należy wymienić: otwartość na innych, tolerancyjną postawę, ciekawość świata, większe możliwości poznawcze (znajomość języków, możliwość odwiedzin kraju pochodzenia drugiego rodzica, posiadanie obywatelstwa).

Osobowość kształtuje się w przestrzeni społecznych interakcji. W naturze każdego człowieka jest bowiem głęboko zakorzeniona potrzeba przynależności. Do ważniejszych mechanizmów tego procesu należą naśladownictwo, będące pewną spontaniczną tendencją istniejącą w psychice dziecka, oraz konformizm rozumiany jako psychiczny trend do zbliżenia swojej postawy do form ogólnie obowiązujących w danej grupie. Dodatkowymi, nie mniej ważnymi czynnikami środowiskowymi, są także: miejsce zamieszkania, tradycja, folklor, kultura itp. Zanim wykształci się poczucie przynależności do większej grupy kulturowej, np. narodowej, wcześniej następuje identyfikacja z najbliższym otoczeniem, czyli rodziną. Internalizacja znaczeń i norm w niej obecnych stanowi zręby późniejszego światopoglądu. Więź rodzinna i lokalna przekształca się w świadomości jednostek, grup w patriotyzm, generalizuje się w poczucie związku z ojczyzną ${ }^{32}$.

Trzeba jednak również dostrzec niebezpieczeństwa. Wśród negatywnych skutków dwukulturowej rodziny generacyjnej można wskazać: poczucie wyobcowania z otaczającego jednorodnego środowiska, czasem także generowaną nietolerancyjną postawą lokalnej społeczności trudność z identyfikacją kulturową i narodową, ograniczenia $\mathrm{w}$ kontaktach $\mathrm{z}$ rodziną jednego lub obojga rodziców wynikające z geograficznej odległości od miejsca zamieszkania. Dzieci $\mathrm{z}$ rodzin wielokulturowych, choć często są doskonale zintegrowane $\mathrm{z}$ obiema kulturami, to jednocześnie nie czują się zupełnie dobrze $\mathrm{w}$ żadnej z nich. Zauważa się, że takie dzieci nierzadko postanawiają zamieszkać w neutralnym kraju, różnym od tych, z których pochodzą rodzice ${ }^{33}$. Z przeprowadzonych w 2002 roku badań wśród potomków małżeństw dwukulturowych mieszkających w Warszawie wynika, że blisko połowa z nich deklaruje tzw. podwójną tożsamość. W przypadku ok. 10\% ankietowanych można mówić o tożsamości ponad- lub pozanarodowej ${ }^{34}$.

${ }^{32}$ T. P a 1 e c z n y: Interpersonalne stosunki międzykulturowe. Kraków 2007 s. 47-48.

${ }^{33}$ E. S o w a-B e h t a n e: Rodziny wielokulturowe. Kraków 2016 s. 41.

34 E. N ow i cka: Rozdroże tożsamościowe. Dylematy potomków malżeństw narodowo mieszanych. „Kultura Współczesna” 2005 nr 3 s. 119. 
Wiara dziecka i system wartości nie może się ukształtować bez związ$\mathrm{ku} \mathrm{z}$ wiarą i życiem religijnym najbliższego otoczenia. To wszystko uzasadnia słuszność stwierdzenia, że rodzina jest dla dziecka najważniejszym środowiskiem budzenia i rozwijania wiary, sama zaś katecheza rodzinna jest naturalną drogą budowania królestwa Bożego przez rodzinę - domowy Kościół ${ }^{35}$. Za w pełni słuszną należy zatem uznać tezę, że wysiłek najlepszej nawet katechezy okaże się daremny, jeżeli nie będzie wspierany przez świadectwo rodziny.

\section{Wnioski}

Przedstawione powyżej socjokulturowe przeobrażenia wskazują na potrzebę poszukiwania pozytywnej odpowiedzi i wyprowadzenia wniosków o charakterze postulatów dla wychowawczej praktyki w rodzinie i duszpasterskich działań Kościoła.

Jeżeli nawet narastający pluralizm społeczno-kuturowy i religijny nie stanowi ekstremalnego niebezpieczeństwa dla religii, to z pewnością determinuje konieczność przeobrażeń w duszpasterskiej działalności Kościoła, większej dynamiki, innego rozłożenia akcentów. Z perspektywy Kościoła widać potrzebę poszukiwania adekwatnych dla obecnego czasu projektów duszpasterskich. Dlatego zmiany dokonujące się w przestrzeni kulturowej w wyniku różnorakich nurtów myślowych winny być stale obserwowane i teologicznie interpretowane, aby można było wypracowywać odpowiadające aktualnym modelom teologicznym imperatywy i programy działania, na podstawie których powinna być prowadzona działalność ewangelizacyjna w konkretnych wspólnotach eklezjalnych $^{36}$. Z kolei z uwagi na globalizację ponowoczesnego świata rodzi się potrzeba zadbania o aksjologiczny fundament proponowanych projektów społecznych. Nie da się bowiem zbudować trwałego systemu społecznego i politycznego bez wsparcia na konkretnym systemie wartości. Nawet jeżeli ta prawda nie jest dostatecznie obecna w świadomości współczesnych konstruktorów ładu światowego, jest niepodważalna i nieodzowna. Historia XX wieku dostarczyła wielu przykładów upadku największych systemów państwowych i międzypaństwowych stworzonych na podstawie błędnych założeń ideologicznych.

Walory społecznej nauki Kościoła katolickiego i innych wspólnot chrześcijańskich są niezaprzeczalne. Tradycje religijne przyczyniają się do podtrzymania świadomości normatywnej (etyki) i więzi międzyludzkiej (solidarności) w wy-

${ }^{35} \mathrm{~J}$ a n P a w eł I I: Adhortacja apostolska Familiaris consortio. Watykan $1981 \mathrm{nr} 49$.

${ }^{36}$ B. D r o żd ż: Uwarunkowania spoleczno-kulturowe ewangelizacji w Polsce na poczatku XXI wieku. W: Ewangelizacja odpowiedzia Kościoła w Polsce na wyzwania współczesności. Red. W. Pr z y g o d a, E. R o b e k. Sandomierz 2011 s. 57. 
miarach społecznych. W myśl nauki Kościoła katolickiego osoba ludzka jawi się jako centrum i źródło porządku społecznego. Uwzględnienie takiej perspektywy z pewnością pozwoliłoby nadać globalizacji bardziej humanitarny i personalistyczny wyraz ${ }^{37}$.

Nie ulega wątpliwości, że różne wersje globalizacji są zagrożeniem dla Kościoła i rodziny. Pogłębiający się relatywizm religijny i moralny, stymulowany przez globalizację, uderza w fundament rodziny. Trzeba zatem uważnie śledzić negatywne skutki globalizacji, a jednocześnie wykorzystywać potencjał przez nią stwarzany.

Szczególnie bolesną egzemplifikacją powyższych analiz jest coraz słabsza kondycja małżeństwa i rodziny. Zwiększająca się liczba rozbitych małżeństw jest wyzwaniem dla duszpasterzy, aby - jak zachęcał Benedykt XVI - „dołożyć maksymalnej troski duszpasterskiej w przygotowanie nowożeńców i uprzednie zweryfikowanie ich przekonań odnośnie do niepodważalnych zobowiązań wpływających na ważność sakramentu małżeństwa" ${ }^{38}$. W opracowanym vademecum na temat przygotowania do sakramentu małżeństwa Papieska Rada do spraw Rodziny wskazuje, że wśród wielu działań duszpasterskich to zadanie jest priorytetowe ${ }^{39}$. W opracowanym dokumencie zwraca się uwagę na rolę i zadania formatorów narzeczonych, zarówno kapłana, jak i dojrzałych par małżeńskich ${ }^{40}$. Papież Franciszek od pierwszych dni swego pontyfikatu zachęca do odważnej refleksji na temat adekwatnego do obecnych wyzwań modelu duszpasterstwa. W adhortacji Evangelii gaudium wyraził nadzieję na podjęcie odpowiednich kroków, ,aby podążać drogą duszpasterskiego i misyjnego nawrócenia, które nie może pozostawić rzeczy w takim stanie, w jakim są"41.

Szybko postępująca globalizacja sprawia, że Kościół traci wiele podmiotów religijnej socjalizacji. Na nowo zatem pojawia się problem przekazu wiary i kultury religijnej. Trzeba szukać odpowiedzi na pytanie, jakie instytucje, środowiska mogą skutecznie zatroszczyć się o przekaz wiary i kształtowanie dojrzałej osobowości religijnej. Stwierdzić trzeba także, że socjalizacja religijna dzieci i młodzieży w dzisiejszym pluralistycznym i zsekularyzowanym społeczeństwie jest niewystarczająca ${ }^{42}$.

${ }^{37}$ J. M a r i a ń s k i: Religia w spoleczeństwie ponowoczesnym. Studium socjologiczne. Warszawa 2010 s. 168.

${ }^{38}$ B e n e d y k t X V I: Adhortacja apostolska Sacramentum caritatis. Watykan 2007 nr 29.

${ }^{39}$ Papieska Rada do spraw Rodziny: Vademecum dotyczace przygotowania do malżeństwa. Propositio. (2010) nr 10.

${ }^{40}$ Tamże nr 32-44.

${ }^{41} \mathrm{Fr}$ a n c i s z e k: Adhortacja apostolska Evangelii gaudium. Watykan $2013 \mathrm{nr} 25$.

42 J. M a riań ski: Szanse $i$ zagrożenia wychowania chrześcijańskiego $w$ niestabilnym świecie. W: Wychowanie chrześcijańskie. Między tradycją a współczesnościq. Pod redakcją Aliny Rynio. Lublin 2007 s. 535. 
W ramach przygotowań do małżeństwa należy ukazywać wagę doboru współmałżonków pod względem religijnym. Na tym polu mogą rodzić się nieporozumienia i konflikty małżeńskie. Ważne jest, aby rozpoznać rozbieżności i osiągnąć porozumienie. Jest to zarazem ostatni moment, aby zrezygnować z małżeństwa. W świadomym podejmowaniu decyzji bardzo pomagają rekolekcje i dni skupienia dla narzeczonych, którzy nie doceniają więzi religijnej ${ }^{43}$. Katecheza przedmałżeńska powinna być czasem intensywnej ewangelizacji, drogą do wiary, do katechumenatu ${ }^{44}$. Jednocześnie ważną funkcją jest pomoc w przyjęciu chrześcijańskiego modelu małżeństwa i rodziny, zwłaszcza w przypadku tych par, które proszą o ślub w Kościele jedynie ze względu na tradycję ${ }^{45}$. Ksiądz Robert Pisula słusznie konstatuje, że ,przystąpienie do sakramentów nie musi wcale wynikać ze świadomego odniesienia człowieka do Boga, który objawia się w Kościele i Chrystusie. Może ono być także owocem naturalnej religijności, która jest właściwa każdemu człowiekowi, bo wpisana jest w jego stworzoną naturę"46.

Ta obserwacja pozwala sformułować postulat szukania jeszcze skuteczniejszej katechezy przedmałżeńskiej. Wydaje się, że nieocenioną rolę w tym względzie mogliby odegrać chrześcijańscy małżonkowie związani z różnymi wspólnotami i ruchami religijnymi. Przekazywane w ramach katechezy przedmałżeńskiej treści mogliby potwierdzić własnym świadectwem ${ }^{47}$. Poszerzenie nauk przedmałżeńskich o świadectwo małżonków, którzy dzielą się doświadczeniem życia w sakramentalnym związku, sprawia, że nauczanie Kościoła dotyczące małżeństwa i rodziny staje się żywe, autentyczne, i nie daje się zepchnąć w sferę teorii.

${ }^{43}$ Drugi Polski Synod Plenarny 1991-1999: Powolanie do życia w malżeństwie i rodzinie. Poznań-Warszawa 2001, nr 41.

44 Papieska Rada do spraw Rodziny: Przygotowanie do sakramentu malżénstwa (13.05. 1996) nr 2; Konferencja Episkopatu Polski: Slużyć prawdzie o malżeństwie i rodzinie (19.06.2009) nr 98.

${ }^{45}$ Drugi Polski Synod Plenarny 1991-1999: Powołanie do życia w malżeństwie i rodzinie. Poznań-Warszawa $2001 \mathrm{nr} 42$.

46 R. P is ula: Potrzeba inicjacji chrześcijańskiej w Kościele polskim. Ku katechezie katechumenalnej. „Katecheta” R. 43: 1999 nr 1 s. 10.

${ }^{47}$ Przykładem takiego zaangażowania może być istniejący od 2008 r. w Olsztynie Ośrodek Formacji Małżeńskiej. Ośrodek współtworzą kapłani, psychologowie, pedagodzy i małżonkowie związani z Ruchem Domowego Kościoła, Odnowy w Duchu Swiętym i Szkoły Nowej Ewangelizacji. Zasadniczym celem jego działalności jest wspieranie małżeństw i rodzin w pokonywaniu kryzysów oraz przygotowanie narzeczonych do małżeństwa. Zob. www.perso nahumana.pl 


\section{Bibliografia}

Bardziej J.: Zakorzenienie $i$ alternacja: tożsamość jednostki $w$ społeczeństwie tradycyjnym. W: Tożsamość i jej przemiany a kultura, Red. P. Oleś. Lublin 2008 s. 215-245.

Bell D.: Kulturowe sprzeczności kapitalizmu. Warszawa 1994.

Bronk A.: Zrozumieć świat współczesny. Lublin 1998.

Danilewicz W.: Oblicza dzieciństwa w rodzinach rozłączonych z powodu migracji zagranicznych rodziców. W: Problemy teorii i praktyki opiekuńczej. Red. B. Matyjas. Kielce 2005 s. 73-84.

Drożdż B.: Uwarunkowania społeczno-kulturowe ewangelizacji w Polsce na poczatku XXI wieku. W: Ewangelizacja odpowiedzia Kościoła w Polsce na wyzwania współczesno$s ́ c i$. Red. W. Przygoda, E. Robek. Sandomierz 2011 s. 45-57.

Dziekoński S.: Specyfika chrześcijańskiego wychowania $w$ rodzinie. W: Wychowanie chrześcijańskie. Między tradycją a współczesnością. Red. A. Rynio. Lublin 2007 s. 693-705 .

Geisler R.: Jednostka i społeczeństwo w postmodernizmie. Częstochowa 1999.

Giddens A.: Europa w epoce globalnej. Warszawa 2009.

Grabowska-Lusińska I., Okólski M.: Migracja z Polski po 1 maja 2004 r.: jej intensywność i kierunki geograficzne oraz alokacja migrantów na rynkach pracy Unii Europejskiej. Warszawa 2008.

Hofstede G.: Kultury i organizacje: zaprogramowanie umystu. Warszawa 2000.

Kawczyńska-Butrym Z.: Migracje. Wybrane zagadnienia. Lublin 2009.

Libiszowska-Żółtkowska M.: Nowe ruchy religijne w globalnej przestrzeni. W: Religia i religijność w warunkach globalizacji. Red. M. Libiszowska-Żółtkowska. Kraków 2007 s. 196-210.

Mariański J.: Religia w społeczeństwie ponowoczesnym. Studium socjologiczne. Warszawa 2010.

Mariański J.: Szanse i zagrożenia wychowania chrześcijańskiego w niestabilnym świecie. W: Wychowanie chrześcijańskie. Między tradycją a współczesnością. Red. A. Rynio. Lublin 2007 s. 523-538.

Matsumoto D., Juang J.: Psychologia międzykulturowa. Gdańsk 2007.

Nikitorowicz J.: Pogranicze tożsamości. Edukacja międzykulturowa. Białystok 1995.

Nowicka E.: Rozdroże tożsamościowe. Dylematy potomków matżeństw narodowo mieszanych. „Kultura Współczesna”. 2005 nr 3 s. 115-130.

Olearczyk T.: Sieroctwo i osamotnienie. Pedagogiczne problemy kryzysu współczesnej rodziny. Kraków 2007.

Paleczny T.: Interpersonalne stosunki międzykulturowe. Kraków 2007.

Pisula R.: Potrzeba inicjacji chrześcijańskiej w Kościele polskim. Ku katechezie katechumenalnej. „Katecheta” R. 43: 1999 nr 1 s. 9-20.

Rostowski J.: Zarys psychologii matżeństwa. Warszawa 1987.

Sobecki M.: Komunikacja międzykulturowa $w$ wymiarze religijnym jako wyzwanie edukacyjne. W: Od wielokulturowości miejsca do międzykulturowości relacji spolecznych. Wspótczesne strategie kreowania przestrzeni życia jednostki, Red. J. Nikitorowicz, J. Muszyńska, B. Boćwinka-Kiluk. Warszawa 2014 s. 107-118. 
Sowa-Behtane E.: Rodziny wielokulturowe. Kraków 2016.

Stopikowska M.: „Przeżylam piekło” - oświadczenia kobiet w świetle pamiętników muzułmanek i żon muzułmanów - między stereotypem a rzeczywistością. W: Etykieta czy drogowskaz. Rola stereotypów w przestrzeniach edukacyjnej różnorodności. Red. M. Łojko, M. Grochalska. Olsztyn 2013 s. 213-224.

Stopikowska M.: Matżeństwa polsko-arabskie: specyfika i zagrożenia. W: Nauki o rodzinie $w$ stużbie rodziny. Red. J. Stala. Kraków 2014 s. 539-549.

Świda-Ziemba H.: Młodzież końca tysiaclecia. Obraz świata i bycia w świecie. Warszawa 2000.

Walczak M.: Psychologiczna prognoza trwałości malżeństw dwukulturowych „Problemy Rodziny" 2001 nr 1 s. 23-28.

Walkowska D.: Społeczne skutki eurosieroctwa. W: Migracje - wyniki aktualnych badań $i$ analiz. Red. O. Dębowska. Kraków 2007 s. 117-120.

Wyżlic M.: Migracja zarobkowa-zagrożeniem dla więzi matżeńskiej. „Cywilizacja” 2010 nr 32 s. 129-138.

Zwoliński A.: Wprowadzenie do rozważań o narodzie. Kraków 2005.

\section{STRESZCZENIE \\ Społeczno-kulturowy i religijny wymiar globalizacji w życiu współczesnej rodziny}

Globalizacja jest procesem wielowymiarowym, obejmującym przestrzeń życia politycznego, gospodarczego, społecznego, kulturalnego, a także religijnego. W niespotykanej dotąd skali dokonuje się transmisja systemów religijnych i ich asymilacja w całkowicie nowych środowiskach. Dlatego religijne konteksty globalizacji powinny być częstszym przedmiotem refleksji socjologów, psychologów i teologów.

Czułym echem procesów społecznych jest rodzina. Różnorodność religijna w rodzinie wielokulturowej może stymulować rozwój duchowy, mobilizując do poszerzenia wiedzy na temat własnej religii i głębszego jej uzasadnienia w konfrontacji z wiarą współmałżonka. Częściej jednak różnice religijne powodują negatywne konsekwencje. W pełni ujawniają się one dopiero w codzienności życia małżeńskiego, w obliczu konkretnych sytuacji i wyborów życiowych, szczególnie, gdy wiąże się to z przyjęciem określonej aksjologii, rozbieżności ocen tego, co jest dobre, a co złe. Nie ulega wątpliwości, że globalizacja w swoich różnych odsłonach może być zagrożeniem dla rodziny, a także całych społeczeństw. Trzeba zatem uważnie śledzić negatywne skutki globalizacji, a jednocześnie wykorzystywać potencjał przez nią stwarzany, aby można było wypracowywać adekwatne do wyzwań programy działań ewangelizacyjnych i duszpasterskich.

Szybko postępujące procesy globalizacji sprawiają, że Kościół traci wiele podmiotów religijnej socjalizacji. Ważne jest zatem, by odpowiedzieć na pytanie, jakie instytucje, środowiska mogą skutecznie zatroszczyć się o przekaz wiary i kształtowanie dojrzałej osobowości religijnej w wielokulturowym świecie.

Słowa kluczowe: globalizacja, rodzina, wielokulturowość, małżeństwa wielokulturowe, różnorodność religijna 


\section{SUMMARY \\ Socio-Cultural and Religious Dimensions of Globalization in a Modern Family Life}

Globalization is a multidimensional process affecting many fields of life, namely politics, economy, society, culture and religion. On an unprecedented scale religious systems are transmitted and assimilated into a new environment. Thus, sociologists, psychologists and theologians seem justified in reflecting upon the religious contexts of globalization.

A family is a litmus paper for social processes. Religious diversity in a multicultural family may broaden the knowledge of one's beliefs and stimulate spiritual development. It appears useful when one is confronted with the spouse's beliefs. However, religious differences often cause negative consequences. They emerge fully during everyday marriage life, when the spouses are facing specific situations and choices between what is good or bad, that refer to axiology. There is no doubt that globalization in some aspects may be a threat to a family and also to whole societies. Therefore, it is advisable to track the negative consequences of globalization and the same time to use its potential to the full. Such an approach will allow to create adequate programmes for evangelization and pastoral work.

Ongoing processes of globalization deprive the Church of many issues of religious socialization. That is why it is crucial to answer the following questions: what institutions and environments may effectively care for the transmission of the faith and form believers with a mature personality in a multicultural world.

Keywords: globalization, family, multiculturalism, multicultural marriages, religious diversity 